\title{
Review on Aesthetic \& Cosmetic Industries in Malaysia -A Way Forward
}

P. M. Ridzuan, N. M. Kummara, MH Islah, V. Jeyamathi, A. A. Nur-Alisyia, Abdul Rahim Ridzuan

To Link this Article: http://dx.doi.org/10.6007/IJARBSS/v11-i6/9939

DOI:10.6007/IJARBSS/v11-i6/9939

Received: 11 April 2021, Revised: 13 May 2021, Accepted: 27 May 2021

Published Online: 14 June 2021

In-Text Citation: (Ridzuan et al., 2021)

To Cite this Article: Ridzuan, P. M., Kummara, N. M., Islah, M., Jeyamathi, V., Nur-Alisyia, A. A., \& Ridzuan, A. R. (2021). Review on Aesthetic \& Cosmetic Industries in Malaysia -A Way Forward. International Journal of Academic Research in Business and Social Sciences, 11(6), 744-755.

\section{Copyright: (c) 2021 The Author(s)}

Published by Human Resource Management Academic Research Society (www.hrmars.com)

This article is published under the Creative Commons Attribution (CC BY 4.0) license. Anyone may reproduce, distribute, translate and create derivative works of this article (for both commercial and non-commercial purposes), subject to full attribution to the original publication and authors. The full terms of this license may be seen

at: http://creativecommons.org/licences/by/4.0/legalcode

\section{Vol. 11, No. 6, 2021, Pg. 744- 755}

Full Terms \& Conditions of access and use can be found at http://hrmars.com/index.php/pages/detail/publication-ethics 


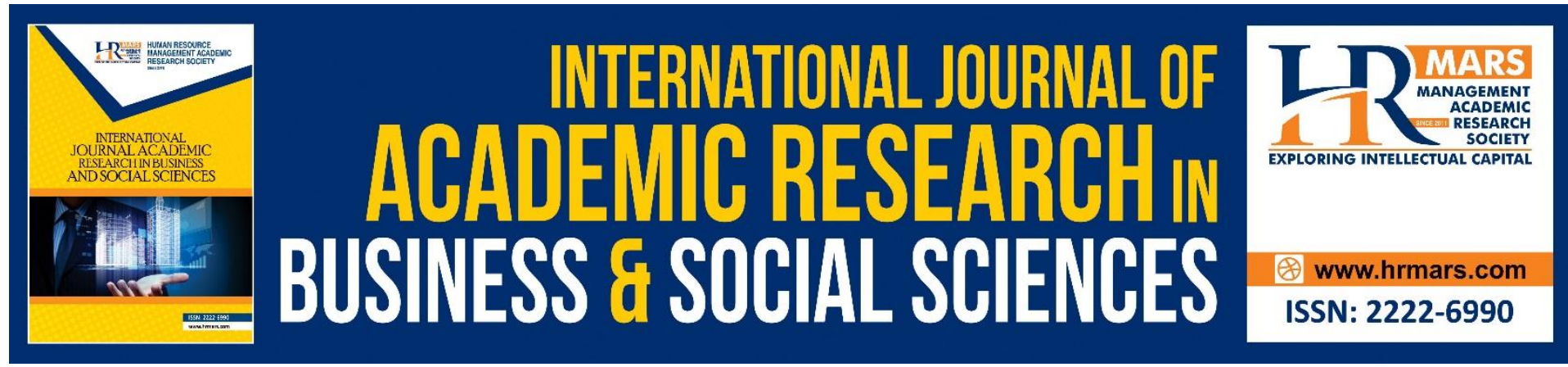

\title{
Review on Aesthetic \& Cosmetic Industries in Malaysia -A Way Forward
}

\section{P. M. Ridzuan ${ }^{1}$, N. M. Kummara², MH Islah², V. Jeyamathi², A. A. Nur-Alisyia², Abdul Rahim Ridzuan ${ }^{3}$}

${ }^{1}$ Department of Research \& Development, Estika Research Centre, 21080 Kuala Terengganu, Terengganu, ${ }^{2}$ Department of Clinical, International Medical School, Management \& Science University, Selangor, Malaysia, ${ }^{3}$ Department of Economics and Finance, Faculty of Business and Management, Universiti Teknologi MARA, Melaka.

Email: drpmridzuan@gmail.com

\begin{abstract}
Cosmetics can be defined as serving to beautify by imparting or improving the beauty of the human. Men and women use cosmetics products to affect impressions of attractiveness and morality significantly. This review paper discusses the issues faced by the cosmetic industry and consumers in Malaysia. The halal dimensions of cosmetics and personal care products include materials and all manufacturing procedures right up to customer distribution, protection, and product effectiveness tests. Lighter and fairer skin is something that everyone craves. However, some cosmetic products can affect health and affect the economy and research development. Due to increasing local awareness regarding cosmetic products, the government has enforced a law that states all cosmetic sellers must register all cosmetic products before sell in the current market to ensure the consumer can use the quality product. There are also several ways to overcome the challenges and improvements in cosmetic industries implemented by different sectors.
\end{abstract}

Keyword: Cosmetics, Industries, Beauty, Health, Aesthetic

\section{Introduction}

A cosmetic item can be characterised as any substance or combination planned to be set in contact with the different outer parts of the human body or with the teeth and the mucous layers of the oral cavity with a view solely or primarily to clean, aroma, change their appearance to address the personal stench ensuring and keeping them in great condition (Spicoli,2010). The Malaysia Personal Care \& Cosmetics Products in 2016 reported that Asian countries represent some of the largest and high potential markets for export-led growth for the USA Personal Care and Cosmetics industries (Tan, 2017). Containing over 20 per cent of USA worldwide fares in the area, Asian nations offer the corrective business over 3 billion possible consumers in the quickest developing worldwide business sectors. However, at present, it turned into a need material where all the gender orientations are utilising it in their daily life. Cosmetics product usage increases where women show great importance on personal grooming, especially all the working women who want to appear 
to be good-looking in society. Moreover, men also tend to buy high-cost cosmetic products to see personal grooming to enhance a youthful appearance. This makes the big brands of cosmetics produce more cosmetic products with good quality and using high-cost materials. Consumers are also ready to buy good products in the market at a high cost. This shows that the cosmetics products market in Malaysia is growing fast (Hassali et al., 2015).

According to The Malaysian External Trade Development Corporation (MATRADE), the Malaysian beautifiers and excellence industry can expand Malaysia's complete exchange execution. In 2016, Malaysia's absolute fares of beauty care products added up to RM1.25 billion, an expansion of $1.4 \%$ when contrasted with 2015. Significant fares included beautifiers and make-up, esteemed at RM513 million, with a portion of $40.9 \%$, trailed by toiletries (RM374.6 million; $29.9 \%$ offer), just as arrangements for hair (RM169.6 million; $13.5 \%$ offer). In the initial eight months of 2017, Malaysia's all out fares of make-up were esteemed at RM796.9 million (MATRADE, 2015). Most multinational companies have manufacturing facilities and offices to produce more products in the markets due to high demand from public and export countries. At the same time, the local manufacturers started to create a brand and focus on Original Equipment Manufacturing (OEM) to fulfil the high demand in the local market. Moreover, they are shifting towards personal and private label cosmetics brands rather than representing foreign brands.

\section{Issues Faced by Cosmetic Industry}

Several cosmetic companies worldwide are competing against one another to capture a multibillion dollar cosmetic market share. Holding a place as one of the best ten makers is fortunate, notwithstanding, worldwide organisations comprehend that they should continually reexamine and rethink their market positions by tuning in to the requests of their clients, picking up tractions in new business sectors, and assessing their authoritative structures. These huge worldwide firms are winding up confronting heavy competition from other well-known brands. Different beautifying agents organisations are pushing ahead by attempting to pick up their position on the lookout and have generally been effective in building up their name (Ana-Maria, 2007). This cause the cosmetic brands to have great competition to gain public trust in their products and produce more products according to their needs.

The developing number of media that investigates sustainability raised customer familiarity with ecological and social issues. However, the essential choice for securing cosmetic items depends on close to personal preferences as natural and moral contemplations are getting progressively significant (Liobikien et al.,2017). Thus, consumers are pushing the cosmetic industry to become "greener",* and at a comparative time, the media and selling strategies previously embraced by certain brands rouse others to expect activity to fortify their situation inside the market (Csorba \& Boglea, 2011). This condition makes the cosmetic brands head towards the sustainable path and cost high to modify the ingredients of the cosmetic products to the greener.

The cosmetics preservation area is a significant one and provides the cosmetics industry and the protection, legal and dermatology communities with fascinating challenges. Consistently, cosmetics items might be utilised. The inclination for microbial pollution of the substance from the hands and body liquids from the consumers and the climate is possible from the second the cosmetics item is used before it is disposed of (Halla et al., 2018). The 
preservatives in cosmetics items prevent the multiplication of microorganisms, prompting a worsening condition of the item and prevent the development of pathogenic microorganisms that may represent a potential risk to the consumer due to continuous usage of the product, regularly by different people, over expanded periods (Halla et al.,2018). It is not irrational to believe that microorganism-toxic agents can still have the ability to cause harmful effects on humans. For the cosmetics industry, balancing those possible detrimental consequences with successful preservation has become a success story (Papageorgiou et al., 2010)

\section{a) Manufacture Facilities for GMP Status}

Progression in innovation makes the cosmetics industry continuously search for new and convincing ingredients that are immediately open, unassuming, and safe. Simultaneously, data concerning the personality and the ingredients in beautifying agents is not promptly accessible in every case. Consequently, confirming the legitimacy and agreeableness of the fixings might be required (Lockley \& Bardsley, 2000). Producers like to use lard to replace oil because lard is more affordable and viable for most countries. In certain religions like Islam and Judaism, the usage of pork and lard in food is illegal because it is against Islamic law. Halal alludes to things or activities allowed by Islamic law for Muslim utilisation and its necessities to reach out to cosmetic and personal care items; normally, at that point, Muslims would need to be sure that the cosmetic and personal care items they use are halal consistent. (AlQardawi, 1995; DSM, 2008)

The United States Food and Drug Administration (USFDA), EU Cosmetic Directive (EUCD), and the ASEAN Cosmetic Directive (ASEANCD) have set out specific standards for the assembling, naming, and offer of cosmetic items. The essential prerequisites of these guidelines concern the well-being of shoppers who utilise cosmetic items. The prerequisite for well-being likewise applies to halal beautifiers to guarantee that the items are, in reality, not unsafe to the client. (DSM,2008). The protection of cosmetics and personal care items in the world are governed and mandated by legislation. Unless their efficacy has been clinically proven, the goods are not allowed to be put on the market. Both facets of the operation and production of cosmetic products are protected by halal cosmetic production activities. According to National Pharmaceutical Control Bureau (NPCB), the manufacturing process must follow severe sterile conditions by good manufacturing practices (GMP) and public health legislation (NPCB, 2009b; NPCB, 2009a).

\section{Issues Faced by Consumers Using Local Cosmetic Products}

Cosmetics products have become an essential thing for every woman. Many women who use cosmetics do not know that make-up could carry several infections if it is not used in the right way. Research that Tejal did in 2009 showed that people are not aware of what kind of ingredients are used in cosmetic products (Tejal et al., 2009). Moreover, they need cosmetics products which give the best results in a short period. This causes the cosmetics brand to add unwanted and prohibited materials in the products which are harmful to the human who is using them. Prohibited chemicals are commonly used to substitute natural ingredients that are costlier and harmful to consumers (Baldemgr \& Kaya, 2010).

Quality item assumes a huge part in surveying consumer's expectation. It may be named a cycle of consistent improvement because the item execution and fulfilment of clients will increase because of persistent changes. Zeeshan and colleagues found in their research that quality is a significant apparatus for making the upper hand (Zeeshan et al., 2013). Also, Chi et al. in 2008 expressed that the buying expectation of customers relies on the item quality, 
and it significantly affects it (Chi et al., 2008). Research that Tsiotsou has finished in 2005 and 2006 found that consumer buying aim is high for a quality item than low-quality items (Tsiotsou,2005; Tsiotsou, 2006). Nowadays, people are not aware of the product quality and prone to buy cheap cosmetic products. Besides, consumers easily used any cosmetics product without referring doctors and aestheticians about the cosmetics ingredients and product efficacies which may cause adverse effects to their skin (Tsiotsou, 2005; Tsiotsou, 2006).

\section{a) Effects of the Unapproved Cosmetic Products on Health}

Unapproved cosmetic products contain harmful ingredients that can cause harm to humans. Several products are banned due to containing scheduled poisons by the National Pharmaceutical Regulatory Department (NPRA) under the Ministry of Health Malaysia, such as heavy metals, Hydroquinone, and tretinoin. Excessive amounts of hazardous heavy metals, such as mercury, lead, and chromium, are commonly found in current cosmetic products (Farrah \& Aliza, 2016). According to the World Health Organization (WHO), the accumulation of toxic chemicals in the skin can be caused by heavy metals in cosmetics products applied to the skin. Besides, this heavy metal can pass through the skin barrier and penetrate blood vessels that are harmful to the nerve and damage the internal organ, such as the liver and kidney (WHO, 2019).

Many studies have reported that most skincare contains hazardous chemicals. Inorganic mercury is one of the most famous chemicals found in various cosmetics and skincare products, such as whitening soaps and creams. This is due to its alleged skin-lightening and anti-freckles property. Women use these products and cosmetics for skin whitening and antifreckle effects. Mercury salt prevents melanin formation by competing with copper in tyrosinase that results in skin lightening. Mercury has two forms: inorganic mercury (mercury iodide) and organic mercury (ethyl mercury). Since inorganic mercury is water-soluble, it can absorb directly through the skin by sweat glands, sebaceous glands, and hair follicles. In comparison, inorganic mercury will deposit in the kidney that will damage the renal and causing reversible proteinuria, acute tubular necrosis, and nephrotic syndrome (Chan, 2011). However, according to a study done in Hong Kong, China, as mercury is applied to the skin and it is absorbed, mercury poisoning can occur, and it is particularly if the stratum corneum is hydrated (Chan, 2011). In the same study, easy percutaneous absorption is also indicated by a rise in urinary mercury excretion and symptoms among the cream containing $5.9 \%$ mercuric chloride. Mercury exposure also can cause damage to the nervous system, which is called neuropathy. He concluded that due to lethal side effects such as systemic absorption, which can cause toxicity of the renal, gastrointestinal, and central nervous system. It was reported that there were various cases from around the world associated with this since the 1970s. The other side effects of mercury are skin rashes, skin discolouration, and scarring. Mercury can also cause the consumer to get infected by bacterial and fungal infections due to a reduction in skin resistance (Okereke et al., 2015).

There are also studies reported on how mercury also affected the reproductive organs, especially for women. A study conducted by the Research Centre in Saudi Arabia's Environmental Health Program reveals that their experimental procedure on mice has shown mercury accumulation in the ovary following the application of skin-lightening cream. A Belgian woman who has been known to use a $1 \%$ mercury product for more than ten years (including during pregnancy and lactation) has elevated levels of mercury in her blood $(91 \mathrm{~g} / \mathrm{l}$ ) and urine (784 g/g creatinine), and similar levels have been detected in her 3-month-old 
daughter. Similar systemic mercury toxicity can occur in fetuses and infants as mercury can pass through the placenta and breast milk (Al-saleh, 2016).

Furthermore, in the year 2014, the Journal of Pharmacy and Pharmaceutical Science has released a journal and article published by University for Women, Karachi, that include some other hazardous chemicals apart from mercury which is Hydroquinone and steroids. Hydroquinone reduces skin pigmentation by competing with tyrosine as a substrate for tyrosinase and via selective damage to melanocytes (Baumann \& Weishberg, 2018). Hydroquinone also makes the skin more susceptible to UV rays. There is concern that it is associated with an increased risk of skin cancer. (Skelly, 2016). Hydroquinone-containing formulations can be used only under the guidance of healthcare professionals. Although Hydroquinone is the only FDA-recognized skin-bleaching chemical, a percentage of more than $2 \%$ is not to be exceeded as it can cause serious side effects, but some dermatologists in other countries recommend it up to $4 \%$. Even then, the duration of 6 months is to be the maximum if it is used daily. The survey was initially done to study the awareness regarding hazards caused by these skincare and cosmetic products, and it turns out, $82 \%$ of women (out of a sample size of 200 women) were unaware of the serious side effects of these hazardouscontaining products can cause. Some of the known side effects commonly associated with hydroquinone use include burning sensation, itchiness, and skin irritation. Pigmentation was included as a long term side effect with hydroquinone use. This study also mentions that there is various evidence that medical professionals often miss regarding the other long-term effects of this stated chemical, which is carcinogenesis. Another famous chemical stated in this article is steroids. Steroids generally work as a famous skin-bleaching chemical by suppressing the amount and function of melanocytes. However, unlike mercury and Hydroquinone, steroid hazardous side effects are considerably well known among the healthcare professions. Cushing syndrome, a cortisol overproduction, is the most common along with immune suppression, osteoporosis, diabetes mellitus, and hypertension (Gul et al., 2014).

Tretinoin is a chemical poison that can be found in some cosmetic products. Doctors usually used it to treat serious acne (KMM, 2019). It will affect the growth of skin cells by gradually destroying the skin layer bit by bit as much as Hydroquinone does. The skin will look peeled, dry, red, painful, and itchy when used, and it will also become more sensitive to sunlight. Tretinoin cream has been commonly used to treat acne, photo-damaged skin, and local irritant dermatitis (Aronson, 2015). With normal use, adverse effects are less. An article on the risks of long-term use of skin-whitening products has been published by the Dermatology Unit of the College of Medicine in Nigeria. Some documented complications of Hydroquinone included dermatitis, exogenous ochronosis, cataract, patchy depigmentation, scleral, and nail pigmentation. Patients were also found to have acquired squamous cell carcinoma at the site of exogenous ochronosis, although it was uncertain if this was an incidental discovery or predicted development from long-term use of Hydroquinone. Another significant finding was the offensive odour produced by the users' sweat called "fish odour syndrome". They concluded that this is due to chemical trimethylamine excretion (a chemical produced by Hydroquinone that suppresses its oxidation) in sweating, breathing, urine and saliva. As for mercury, this article divided its side effect into two types which are acute and chronic. The two most common acute presentations for acute mercury toxicity are pneumonitis and gastric discomfort, while neurological and nephrotoxicity are the most common of acute toxicity. Nephrotic syndrome, membranous and proliferative glomerulonephritis were some of the well documented renal involvement associated with 
mercury toxicity. When addressing steroids, they include steroid addiction syndrome alongside other well-known steroid complications. This syndrome is stated as a result of a long term daily application of more than 1-month period of steroids. The site of application of this chemical shows "withdrawal" symptoms by producing a serious burning sensation and can only be relieved by more steroid application (Olumide et al., 2008). The use of non-halal porcine ingredients and animals that are not slaughtered under Islamic rule. Manufacturers tend to use lard as an oil alternative in most countries because lard is cheaper and easier to access (Hashim \& Mat, 2013). According to Islamic, lard is also forbidden to their religion. Furthermore, collagen and placenta are also used in cosmetic products, which give good results for the human. Therefore, anything of human origin is not permitted in halal practice. Human placenta and human hair cysteine are not allowed in halal cosmetics (Hashim \& Mat, 2013).

\section{b) Effects of the Unapproved Cosmetic Product on Economy}

In most countries, the cosmetic industry has spread quickly. Since the demand for cosmetic products is increasingly growing, cosmetic companies and industries have to ensure that quality products can be made. However, some cosmetic manufacturers do not comply with the safety requirements of their cosmetic products because they still use banned substances and dangerous chemicals as ingredients in their products because of their cheap price and efficacy, despite being aware of the potential adverse reactions that may occur (Hazrina et al., 2020). Some have also disguised their fake cosmetic products with names and packaging identical to the original products and marketed them at cheaper prices by some reckless manufacturers (Hazrina et al., 2020).

The cosmetics industry is one of the fastest-growing markets. Asia Pacific's market is the second-largest market after the Western European market, which has risen to more than US\$70 billion (Azmi et al., 2017). Malaysian spent US\$407 million on toiletries and cosmetic products in 2013. Skincare products are the key for cosmetics markets, which worth US\$229 million, and eye colour cosmetics, which worth US\$20.6 million. Malaysia imported around US\$295 million worth of cosmetics and toiletries in 2013, and the United States, Japan, and Thailand are the top three importing countries (Azmi et al., 2017). It was found that Malaysian consumers' interest to buy imported cosmetic brands compare to the local cosmetic brand.

However, based on exportation local cosmetic has a contribution to our economic sector. One of the achievements, in the first seven months of 2017, our local cosmetic product achieved RM796.90 million, $37 \%$ export to China compared to 2016 , which is $26 \%$. It shows that our local cosmetic product has increased by $11 \%$ of exportation to China. Based on MATRADE, the exportation of our local cosmetic product to China need to be enhanced (BERNAMA, 2017). Since cosmetic products are one of our sources of economy, the government takes this matter seriously to ensure the quality of the product is good and safe to use.

\section{c) Effects of the Unapproved Cosmetic Product on Research Development}

Cosmetics are one of the components that important make people appealing. For most people, especially women, it is becoming a trend to use cosmetics daily. As Rodda stated in 2004, some Asians appear to overdo their use, such as the whitening ritual. They chose items randomly to be used without extensively investigating the effectiveness and negative effects of usage (Rodda, 2004). The skin lightening market is one of the fastest-growing cosmetic industries in the world and is projected to be worth US\$ 31.2 billion by 2024 . In India, the skin 
lightening product contributes $50 \%$ of the skincare market (including products with and without mercury) and is estimated to be worth US\$ 450-535 million (WHO, 2019).

In line with the present circumstances, consumers search for items containing active ingredients that have major beneficial effects. However, some cosmetic manufacturers use banned substances and chemicals as ingredients in their products, despite being aware of potential adverse reactions. The most common product that contains prohibited material is a skin whitening product. There is extensive use of skin lightening and skin whitening in Malaysia. In 2004, Synovate Regional Survey reported that $61 \%$ of Malaysian women felt they looked younger with light and fair skin. Skin lightening and skin whitening is a major hit in the market. The study of cosmetic practice in Malaysia is very minimal, particularly about the practice and knowledge of skin lightening (Zulaikha, 2015). The Malaysian authority known as the National Pharmaceutical Control Bureau (NPCB) is actively involved in controlling the safety of cosmetic products. The NPCB aims to assure the quality in the Malaysian market of notified cosmetic products and ensure compliance with the standards and specifications set by the Ministry of Health, Malaysia.

\section{Way Forward and Challenging in Cosmetic Industries}

\section{a) Government policy (enforcement) under the Ministry of Health Malaysia ( $\mathrm{MOH})$}

Back in 1984, the government has enforced a law that states all cosmetic products will be under the government of the Control of Drugs and Cosmetic Regulations (CDCR), and it was categorised under the Sale of Drugs Act 1952. Therefore, all beauty or cosmetic products should be legally registered under the Ministry of Health Malaysia and the Drug Control Authority (PBKD) before being marketed in Malaysia (NPRA, 2020). The ASEAN Cosmetic Directive $(A C D)$ is the authority for controlling cosmetic products in Malaysia before $1^{\text {st }}$ January 2008 through a notification procedure. The Cosmetic Notification Holder (CNH) was obliged to abide by all the specifications set out in the Guideline and to make a declaration through the National Pharmaceutical Regulatory Agency (NPRA) to the Director of Pharmaceutical Services (known as DPS). If the regulations and guidelines were not abided by, the cosmetic sellers would be charged by the law (NPRA, 2020).

The law also urged the sellers not to produce, sell, import, or own any cosmetic products unless notified legally. No sellers can undertake such activities without advanced notice to the DPS (NPRA, 2020). Furthermore, all certified cosmetic products were continuously monitored by NPRA through the Quality Monitoring Program of Notified Cosmetic Products to ensure that every cosmetic product on the market complies with the guidelines, laws, quality, and safety requirements. Their job descriptions include the screening of product information, audit of Product Information Files (PIF), sampling of products for quality testing, monitoring label compliance, an inspection of the manufacturer's premises to ensure compliance with APB requirements, and monitoring of advertised products advertisements. In addition to that, NPRA also monitors reports of adverse effects and conducts investigations into complaints received regarding cosmetic products (KKM, 2019).

Below are the laws that must be observed as per the Guidelines for Cosmetic Controls in Malaysia:-

I. Particulars of a product including product name, product type, intended use, and product presentation

II. Name and address of the manufacturer(s) and assembler(s), if any

III. Name, address, and valid contact number (and e-mail address) of the $\mathrm{CNH}$

IV. Particulars of person representing the company of $\mathrm{CNH}$ including valid contact number 
V. Name and address of the importer(s), if any

VI. Full product ingredient list (the content, i.e. percentage (\%) of the restricted ingredients must be declared)

VII. Letter of Authorisation/Letter of Declaration/Letter of Contract Manufacturing, where applicable

VIII. Label(s) of the product

If a product does not comply or fails to abide by the requirements of the guidelines and laws, the product notification status will be cancelled by NPRA. That particular company will be instructed to take back the product from the market (KKM, 2019).

Individuals who violate the law that has been regulated by the Drugs and Cosmetics Control Regulations (DCCR) will be fined up to RM 50,000 or 3 to 5 years of jail. Meanwhile, companies that repeat the same offence will be fined up to RM 100,000 (Hisyam, 2018)

\section{b) Educating the public regarding the cosmetic product}

Minority consumers did not realise the risks of using chemical contained cosmetics towards their health. Nevertheless, a large amount of them acknowledged the side effects of these products, therefore, demanded organic skincare and cosmetics that are certified (KKM, 2019). Even though the cosmetics company is fully responsible for ensuring that the cosmetic products on the market are safe and of high quality, we must be aware of what we apply to our bodies as consumers. Consumers need to make wise choices when choosing cosmetic products in the market (KKM, 2019).

A study by Tejal in 2013 was conducted to observe whether consumers were aware of the specific details of the cosmetic products they have purchased. Among the components that consumers often look into before buying cosmetic products were the expiration date, ingredients, also certain benefits and side effects of the ingredients to their general health. As per the study, both males and females have said that they read the safety warning before purchasing products which justifies that customers are also concerned about the hazardous effect. On top of that, most consumers checked the manufacturing/expiry date before buying cosmetics (Tejal et al., 2013).

Moreover, consumers should be educated on the harmful effects of cosmetic products on their general health. Hydroquinone, tretinoin, and betamethasone valerates are harmful ingredients that require permission from the Drug Control Authority and a consult from a medical practitioner before usage (Malaysiakini, 2020). The use of products containing such ingredients without the supervision of a health professional may cause the following adverse side effects such as irritation to the skin, pigmentation and can cause damage to the organs (Hisyam, 2020). The public can check the notification status or the latest lists of cosmetic products using prohibited substances directly on the official NPRA website at www.npra.gov.my or via the NPRA Product Status application, which may be downloaded from the Google Play Store before the purchase of a cosmetic product on the market (KKM, 2019).

\section{c) Overcoming the challenges and improvement in cosmetics industries}

Accelerating investment by small and medium-sized enterprises (SME) leads also helps improve the cosmetics industries. An increase in the coordination of their investment-related to advanced manufacturing with private and non-federal investors benefits both the cosmetics industries to produce and endure in their respective fields and the SME in the economic sense. Strengthening workforce skills by expanding the number of workers who 
have skills by growing the manufacturing sector directly allows more products to be produced. This not only involves the manufacturing department but also includes the research and development (RND) department, allowing more research on product development.

Education and training systems should be done to the manufacturer and cosmetic founder, which this training allows more efficient ways to produce a product. Not only in the level of manufacture, as a provider, but a workforce with efficient knowledge regards will also the product be able to deliver the correct need to the customer, especially in the field of hands-on beauty products. Statistical process for the FDA- Regulated industry explained the manufacturer's establishment and maintenance for Corrective and Preventive Action (CAPA). This is the key to produce a quality product. The journal stated about analysing processes, work operations, concessions, quality audit reports, service records, and complaints returned product needs to be statically recorded for further enhancement. This statistical methodology shall be employed when necessary, to detect recurring quality problems.

\section{Conclusion}

The cosmetic industry in the world is growing rapidly. This is a direct result of the expanding number of working ladies and men, expanded urbanisation, and the expanding mindfulness because of education. Explores identified with customers' buying and use of beautifiers are as yet required because it appears to be that shopper conduct is changing after some time. The brand also impacts the client conduct, which can impact the purchase or not as the brand's name assumes a significant function in buying choices. Individuals consuming cosmetic products are still not aware of the product's ingredients, which may cause affect their health. The use of heavy metals (mercury, lead), Hydroquinone, and tretinoin should be strictly prohibited. Systemic absorptions and accumulation of mercury causing renal, gastrointestinal, and central nervous system toxicity effects should be emphasised to the public. The public also should be warned about the prolonged use of Hydroquinone and tretinoin can cause skin redness and other side effects that can cause harm to health. Nowadays, many local products sell cosmetic content prohibited ingredients which will cause the public interested in buying imported cosmetic brands compared to the local cosmetic brand, which can affect the economy. So, as a consumer, we need to support local products to support our country. Not all local products sell cosmetic content dangerous materials, and there are many more local products that clinically safes and have good quality free from prohibited ingredients to support our country on the economy and research development. Before purchasing, consumers are strongly advised to check the components or ingredients in the cosmetic to reduce risks or reactions to the skin and overall well-being. The public should be educated thoroughly regarding this issue. Among the components that the public should look into before buying cosmetic products are the expiration date, ingredients, certain benefits, and side effects of the ingredients. Regarding the government policy concerning cosmetic controls in Malaysia, if a certain beauty or cosmetic product does not comply with the rules and regulations, NPRA will take action by removing the product notification status. The company responsible will be asked to stop producing them, and further legal measures will be taken. The government has also provided an official website as an easier way for consumers to look into cosmetic products' notification status or the list of ingredients. Otherwise, more opportunities should be given to small and medium enterprises to enhance and increase the consumer base. Finally, proper research and statistical data collection are required for quality control. 


\section{References}

Al-Saleh, I. (2016). Potential health consequences of applying mercury-containing skinlightening creams during pregnancy and lactation periods. International Journal of Hygiene and Environmental Health, 219(4-5), 468-474.

Chan, T. Y. K. (2011). Inorganic mercury poisoning is associated with skin-lightening cosmetic products, Clinical Toxicology (Phila), 49(10), 886-891.

Gul, S., Monazzam, A., Rashid, H., \& Ali, S. M. (2014). Hidden killers for women : Mercury, steroids, and hydroquinone in skin whitening and bleach creams. Journal of Pharmacy and Pharmaceutical Sciences 2(1). 9-17.

Olumide, Y. M., Akinkugbe, A. O., Altraide, D., Mohammed, T., Ahamefule, N., Ayanlowo, S., \& Onyekonwu, C. (2008). Complications of chronic use of skin lightening cosmetics, International Journal of Dermatology, 47(4), 344-353.

Hassali, A. M., \& AL-Tamimi, S. K. (2015). Malaysian cosmetic market: Current and future prospects. Pharmaceutical Regulatory Affairs, 4(4), 10-13.

Hisyam, D. (2020). Three cosmetic products found to contain poison. Malaysiakini. Retrieved from https://www.malaysiakini.com/news/522496

KKM. (2019). Kawalan produk komestik di Malaysia. Kementerian Kesihatan Malaysia. Retrieved from http://www.myhealth.gov.my/kawalan-produk-kosmetik-di-malaysia/

NPRA. (2020). Guidelines for control of cosmetic products in Malaysia. National Pharmaceutical Regulatory Agency. Retrieved from

https://www.npra.gov.my/index.php/en/cosmetic-main-page.html

Tejal, P. N., Nishan, D., Amisha, J., Umesh, G., Desai, K., \& Bansal, R. (2013). Cosmetics and health: Usage, perceptions, and awareness. Bangladesh Journal of Medical Science, 12(4), 392-397.

Al-Qardawi, Y.(1995). The lawful and the prohibited in Islam (p. 1-78). Islamic Book Trust, Kuala Lumpur.

ASEAN. (2008). ASEAN Cosmetic Directives (ACD). ASEAN Secretariats, Jakarta, Indonesia.

Abd Rahman, A., Asrarhaghighi, E., \& Ab Rahman, S. (2015). Consumers and halal cosmetic products: Knowledge, religiosity, attitude and intention. Journal of Islamic Marketing, 6(1), 148-163.

Csorba, L., \& Boglea, V. (2011). Sustainable cosmetics: A major instrument in protecting the consumer's interest. Regional Business Study, 3, 167-176

DSM (Department of Standards Malaysia) (2008). Malaysian Standard MS 2200: Part 1:2008 Islamic Consumer Goods - part 1: Cosmetic and Personal Care - General Guidelines (16). Shah Alam, Malaysia: Department of Standards Malaysia. Printing Department, SIRIM Berhad

Epstein. (2006). Cosmetics preservation: Sense and nonsense. Clinical Dermatology, 24, 551-552.

EU. (1976). EU Cosmetic Directive 76/768/EEC. The European Union. FDA's Testing of Cosmetics for Arsenic, Cadmium, Chromium, Cobalt, Lead, Mercury, and Nickel Content, 202.

Halla, N., Fernandes, I. P., Heleno, S. A., Costa, P., Boucherit-Otmani, Z., Boucherit, K., Rodrigues, A. E., Ferreira, I. C. F. R., \& Barreiro, M. F. (2018). Cosmetics preservation: A review on present strategies. Molecules, 23(7), 1571.

Hashim, P., \& Hashim, M. D. (2013) A review of cosmetic and personal care products: Halal perspective and detection of ingredient, Pertanika Journal of Science \& Technology, 21(2), 281-292. 
Hassali, M. A., AL-Tamimi, S. K., Dawood, O. T., Verma, A. K., \& Saleem, F. (2015) Malaysian cosmetic market: Current and future prospects. Pharmaceutical Regulatory Affairs, 4(4), 1-3.

Lockley, A. K., \& Bardsley, R. G. (2000). DNA-based methods for food authentication. Trends in Food Science and Technology, 11, 67-77.

National pharmaceutical control bureau. (2009a). Guidelines for control of cosmetic products in Malaysia (Revision 02). National Pharmaceutical Control Bureau, Ministry of Health, Malaysia.

National pharmaceutical control bureau. (2009b). Guidelines on good manufacturing practice for cosmetic, Annex 1, Part 9. Guidelines for Control of Cosmetic Products in Malaysia (Revision 02). National Pharmaceutical Control Bureau, Ministry of Health, Malaysia.

Tsiotsou, R. (2006). The role of perceived product quality and overall satisfaction on purchase intention. International Journal of Consumer Studies, 30(2), 207-217.

Papageorgiou, S., Varvaresou, A., Tsirivas E, \& Demetzos C. (2010). New alternatives to cosmetics preservation. Journal of Cosmetic Science, 61(2), 107-23.

USFDA. (2004). Chapter VI: Cosmetics. In the Federal Food, Drug, and Cosmetic Act (FD\&C Act). U.S. Food and Drug Administration, USA.

WHO (2017). Mercury and health. Key facts. Geneva, World Health Organization 